\title{
Family history and perceived vulnerability to some common diseases: a study of young people and their parents
}

\author{
Maggie Ponder, Joanna Lee, Josephine Green, Martin Richards
}

\begin{abstract}
During the last two decades, health promotion has concentrated on lifestyle factors. However, recent research in genetics has shown that inherited susceptibility may be important in many common conditions. This raises questions about how these two different messages are integrated into people's beliefs about their own susceptibility. We report a study based on interviews with 58 young people, who had all recently completed the National Curriculum science course including basic human genetics, and 54 of their parents. We aimed to examine the extent to which people take account of family history when considering their susceptibility to health risks, with comparisons being made between generations, gender, and between different diseases. Family health histories were compared between generations and the relationship between reported family history and perceived vulnerability was examined. Family health history was seen as more relevant for a perceived vulnerability to heart disease and diabetes than cancer, while actions and behaviour were seen as important in determining the chance of developing heart disease and cancer but less so for diabetes. Chance was seen as an important factor in the risk of cancer and diabetes, but was barely mentioned in connection with heart disease. Nearly half of those who reported affected family members with heart disease or cancer did not perceive this to have any effect on their own susceptibility. Notably, women were much more likely than men to see the presence or absence of affected relatives as being relevant to the chances of developing cancer.
\end{abstract}

Differences were found between generations in the reporting of the family tree and in knowledge of health of family members. Although words such as genes, chromosomes, and DNA were used by both generations there was no evidence of any understanding of the process of inheritance in scientific terms.

( $f$ Med Genet 1996;33:485-492)

Key words: young people; family health history; perceived vulnerability.

During the last two decades, health promotion has concentrated on lifestyle factors. People have been increasingly encouraged to take re- sponsibility for their own health and there has been a shift in medical services towards presymptomatic prevention and away from simply giving medical advice and treatment once illness has developed. Taking responsibility for one's own health includes such things as diet and exercise regimens, as well as taking part in screening programmes (for example, blood pressure checks and cervical smear tests). These policies may reinforce the idea that the development of illness is somehow in one's own control and so it is up to the individual person to remain healthy. ${ }^{1}$ However, recent research in genetics has shown that inherited susceptibility may be important in many common conditions. This shifts the control out of the hands of the individual person, since people cannot be held responsible for their genetic endowment. Some of this genetic research has had wide media coverage with reports of the potential for genetic testing. There is currently much discussion among health planners about how these new developments might influence service provision particularly in relation to common diseases. $^{2}$

It is well recognised that physical and other characteristics, as well as diseases, are often described as "running in the family" "-6 and there has been discussion as to how this is integrated into people's understanding of particular situations, such as susceptibility to heart disease. ${ }^{6}$ However that is little evidence of a wide public understanding of inheritance in genetic terms. ${ }^{78}$

The recent developments in human genetics and molecular biology have been reflected in the school curriculum. In Britain the National Curriculum science course aims to educate young people about genetics in the following way:

"Using the concept of the gene, they [the pupils] should explore the basic principles of inheritance in plants and animals and their application in the understanding of how sex is determined in human beings and how some diseases can be inhertited."9

The recent House of Commons Science and Technology Committee report ${ }^{10}$ has argued that more genetics should be introduced into the school curriculum in order that the population is able to take part in debates about new genetic technologies.

As a result of these developments we might expect that young people who have received the new teaching would have a better understanding of genetics and how their own family 
Table 1 Details of sample by age and sex

\begin{tabular}{lllc}
\hline & Male & Female & Total \\
\hline $\begin{array}{l}\text { Young people } \\
\text { Mean age 16.8 y }\end{array}$ & 23 & 35 & 58 \\
$\quad$ Range 16-18 y & & & \\
$\begin{array}{l}\text { Adults } \\
\quad \text { Mean age 46.5 y } \\
\text { Range 36-74 y }\end{array}$ & 19 & 35 & 54 \\
Total & 42 & 70 & 112 \\
\hline
\end{tabular}

history of disease may influence their vulnerability to particular diseases than their parents, who are less likely to have been taught any genetics at school.

There has been a small amount of research on the extent to which members of families may be aware of the occurrence of disease among their relatives. In the case of cancer ${ }^{11}$ and heart disease ${ }^{12}$ studies have shown, not surprisingly, that information about near relatives is more accurate than for more distant ones. Hastrup et $a l^{13}$ also showed that knowledge of a family's health history was limited to near relatives. They concluded, somewhat surprisingly, that family health history information was learnt during childhood and does not extend much thereafter. None of these studies related knowledge of family health history to perception of risk felt by people nor considered how such knowledge might influence behaviour.

A knowledge of people's understanding of the role of inheritance in the aetiology of common diseases is important for the production of appropriate educational material and in order to inform doctors about how best to communicate with their patients about genetic predisposition. The present study aimed to examine the extent to which people take account of family history when considering their susceptibility to health risks, with comparisons being made between generations, gender, and between different diseases. Family health histories were compared between generations and the relationship between reported family history and perceived vulnerability was examined.

\section{Methods}

\section{SAMPLE}

The sample consisted of 58 young people (aged 16 to 18 ) who had completed the National Curriculum the previous year, and their parents $(\mathrm{n}=54)$ (table 1). Young people were recruited from a local further education college which caters for a wide range of academic abilities. Two researchers spoke to tutor groups in college time and asked for volunteers. Groups were chosen to cover a range of courses and academic achievements (table 2). Overall about $50 \%$ agreed to take part but there was wide variation between subject groups (from 11 out of 16 (sport and leisure) to one out of eight (electrical and technical)). Participants received a $£ 5$ gift token after the interview. With the young person's permission, a letter was written to the parent(s) asking if they would take part. In 36 of the 58 families at least one
Table 2 Courses being studied and academic achievement of young people measured by number of $A-C$ grades achieved at GCSE (General Certificate of Secondary Education) at age $16 / 17$ years

Courses being studied at time of interview

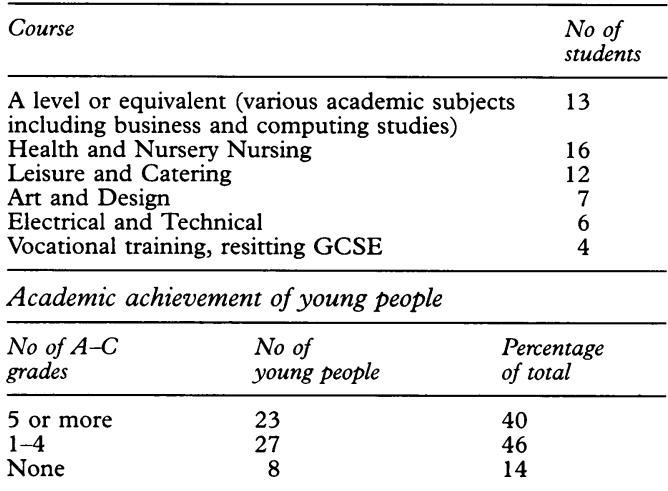

parent agreed: 35 mothers and 19 fathers took part, with 18 couples being interviewed together. Most (89\%) of the parents interviewed had semi-skilled or professional occupations and $11 \%$ had a university degree. The parents were mostly interviewed in their own homes and the young people mostly in college. All the interviews were tape recorded with the subject's permission and transcribed. All interviews were carried out by $\mathrm{JL}$ and $\mathrm{MP}$, each interviewing approximately half of the young people. The parent(s) were then interviewed by whichever interviewer had not interviewed the young person. No information was passed on before the parental interview to avoid the risk of biased questioning and to maintain confidentiality. We could not ensure that the young people would not report the interview content to their parents, but there was no evidence that this had happened. The parents were, in fact, remarkably uninformed about the research by their children.

\section{INTERVIEWS}

Interviewees were told that the research was about health and were not initially told about our interest in family health history, since an aim was to discover how frequently this would be mentioned spontaneously. The interview was in two parts and was the same for both generations.

In part 1,14 conditions were presented and for each, the interviewee was asked: "Compared to other people of your age do you feel that you are more or less likely to get... [for example, cancer], or the same?". They were then asked why this was and any spontaneous reference to inheritance or family history was pursued in the interview. In the second half of the interview, a family tree was drawn and the family health history taken. We made no attempt to verify information that we were given but we were able to compare the family trees for the two generations. This paper reports on only three of 14 conditions, heart disease, cancer, and diabetes; others will be reported elsewhere. These were chosen because all have been identified as common disorders where inheritance can be a factor and have been 
Table 3 Percentage feeling that they are more/less/equally likely to get heart disease/ cancer/diabetes than their peers (whole sample, $n=112$ )

\begin{tabular}{lllll}
\hline Disease & $\begin{array}{l}\text { More likely } \\
(\%)\end{array}$ & $\begin{array}{l}\text { Less likely } \\
(\%)\end{array}$ & $\begin{array}{l}\text { Equally likely } \\
(\%)\end{array}$ & $\begin{array}{l}\text { Likelihood not } \\
\text { known (\%) }\end{array}$ \\
\hline Heart disease & 41 & 23 & 30 & 6 \\
Cancer & 34 & 10 & 46 & 10 \\
Diabetes & 13 & 40 & 21 & 26 \\
\hline
\end{tabular}

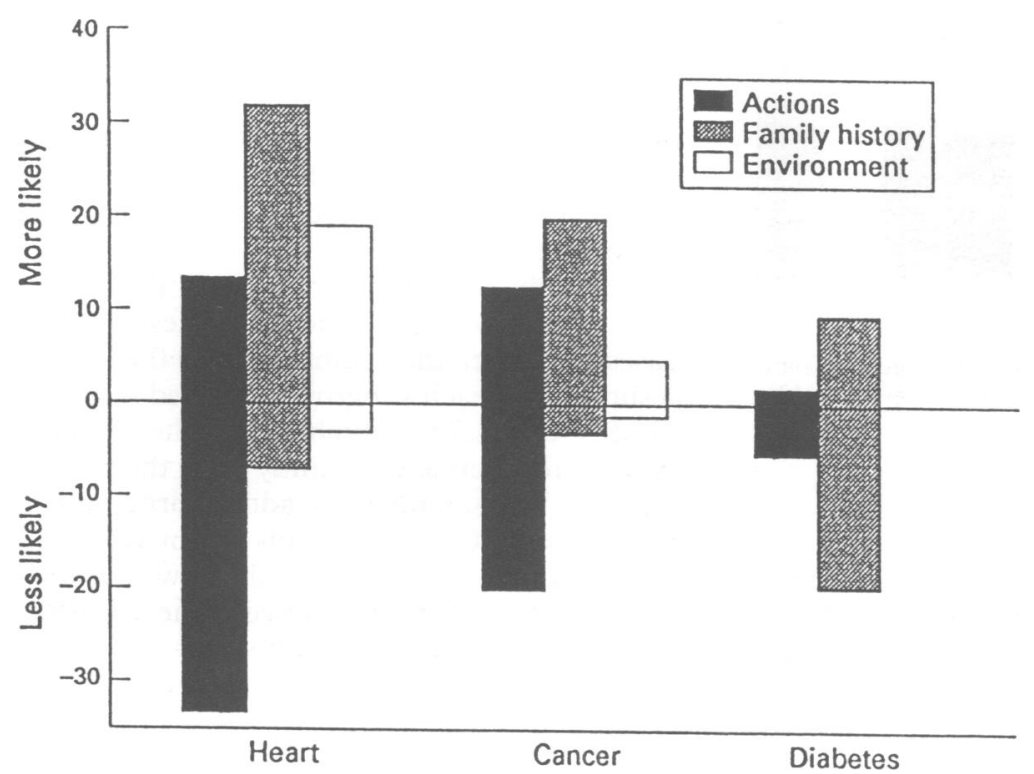

Figure 1 Number of people citing actions, family health history, or environment as factors which make them more or less likely than their peer group to get heart disease, cancer, or diabetes $(n=112)$. in the genes", "I think that is inherited". (3) Environment (including social and physical): for example, "I live in the country", "My work is stressful", "I work in a smoky place". (4) Chance: for example, "It can happen to anyone".

For each condition we recorded reasons given for feeling personally more or less susceptible. We also recorded separately statements indicating that a factor was relevant in general but not to the person being interviewed. Each person could give up to two reasons and could potentially indicate that they felt both at increased likelihood because of one factor but decreased because of another. All the interviews were coded independently by MP and $\mathrm{J}$ with almost complete agreement; the few differences were resolved by discussion. Where appropriate, $\chi^{2}$ analysis was carried out or Cochrane $Q$ test where there were three or more related samples, using the Statistical Package for the Social Sciences.

The parts of the interviews concerning the reported family health history and perceived susceptibility because of family history were analysed for common themes using a grounded theory approach, ${ }^{14}$ that is, themes and hypotheses were derived from the interviews themselves rather than using a priori codings.

\section{Results}

PERSONAL SUSCEPTIBILITY

Overall assessment of personal susceptibility relative to peer group varied between diseases (table 3). Forty one percent thought they were more likely than their peers to get heart disease and $34 \%$ more likely to get cancer compared with only $13 \%$ for diabetes $(p<0 \cdot 0001)$. Conversely, $40 \%$ felt less vulnerable to diabetes with $23 \%$ for heart disease and only $10 \%$ for cancer $(p<0 \cdot 0001)$. Fig 1 shows the numbers of each group who felt that they were personally either more or less likely to get cancer, diabetes, and heart disease subdivided by the reasons given. Chance was always seen as a factor that needed to be taken into consideration, but was not given personal meaning. Family health history and environment were more often cited as raising one's susceptibility than lowering it, except where diabetes was concerned. For diabetes environment was never mentioned and a lack of any affected relative was cited as decreasing vulnerability more often than the presence of an affected relative was seen as increasing it. For all conditions, actions and behaviours were more often seen as decreasing susceptibility rather than increasing it.

The research combined quantitative and qualitative approaches to allow us to look at individual explanations and perceptions as well as those of the groups as a whole.

The reasons given for susceptibility (or nonsusceptibility) to the various conditions were coded as follows. (1) Actions and behaviours: for example, "I keep my weight down", "I smoke", "It is to do with what you eat". (2) Heredity/family history: for example, "My Dad has it", "No one in our family has that", "It's

\section{Sex differences}

Females of both generations were much more likely than males to feel at increased likelihood of getting cancer because of affected relatives $(p<0 \cdot 005)$. For the other two diseases there were no significant sex differences in feeling susceptible because of affected relatives. There were no other significant differences between the sexes. 


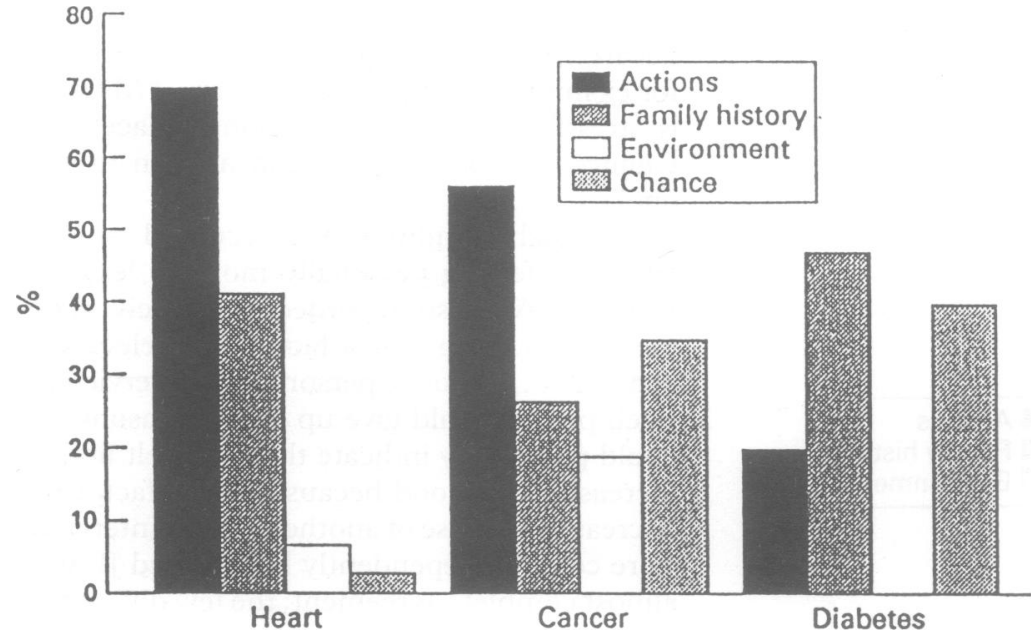

Figure 2 Percentage of the sample citing actions, family health history, environment or chance as being relevant to the aetiology of heart disease, cancer, or diabetes $(n=112)$.

\section{Generation differences}

Parents were more likely than the young people to feel that an absence of relatives with diabetes decreased their personal susceptibility $(\mathrm{p}=$ $0 \cdot 05)$. There were no other significant differences between the generations.

FACTORS CITED AS RELEVANT TO SUSCEPTIBILITY FOR OTHERS AS WELL AS ONESELF

We added together all the answers indicating that people felt personally more or less susceptible to the three dieases with answers indicating that a factor was generally, but not personally, important. This gave us an overall indication of which factors were perceived as being relevant to the three different conditions.

As fig 2 shows, there was considerable variation in perceptions of the relevance of the factors influencing the different conditions. Forty percent of the sample cited family health history with regard to heart disease, $36 \%$ for diabetes, and $25 \%$ for cancer $(\mathrm{p}<0.05)$. Chance was seen as an important factor in cancer and diabetes, but only $3 \%$ mentioned it in connection with heart disease $(p<0.0001)$. Environment was not cited at all for diabetes with only $6 \%$ for heart disease and $18 \%$ for cancer $(p<0.002)$. Actions and behaviour were seen as important for heart disease $(68 \%)$ and cancer $(53 \%)$, but less so for diabetes $(15 \%)$ $(\mathrm{p}<0 \cdot 0001)$.

\section{Sex differences}

Most notably, while women often felt that susceptibility to cancer was influenced by having affected relatives $(38 \%)$, men seldom did $(8 \%)$ $(\mathrm{p}<0.001)$.

There were no significant differences between the generations.

\section{REPORTING OF FAMILY HISTORY}

Young people reported fewer relatives over all in their families. The adults knew more details about their parents' generation than most of the young people did about theirs. In none of the families was the two generations' reports of family history identical. Typical differences in reports of family trees are illustrated by the two reports of the same family in fig 3. In this family the two informants are the two arrowed subjects. Not only does this illustrate the difference in the number of relatives reported by the young person and his mother, but also the conflicting information given.

There were differences noted between young people and adults in the nunber of family members said to have had heart disease $(p<0.005)$ or cancer $(p<0.005)$, with the parents reporting more cases. No such differences were shown for diabetes but there were fewer reported cases in both generations.

The only gender difference was that males were more likely to report families with no cases of cancer than females $(p<0 \cdot 05)$. Table 4 shows how each subgroup reported numbers of affected relatives. Eighteen of the 19 adult men were interviewed jointly with their wives and the wives tended to add information in these cases. We felt that this might have distorted our results and that there would have been greater differences between the sexes had we interviewed them separately.

INTERPRETING SUSCEPTIBILITY OWING TO THE PRESENCE OR ABSENCE OF AFFECTED RELATIVES Comparatively few of the people who reported that they had no relatives with a condition reported feeling less vulnerable because of it. Feeling less vulnerable because of having no affected relatives was most often seen in the answers given about diabetes $(17 \%$ of the whole sample) and seldom used for heart disease $(6 \%)$ or cancer $(3 \%)$. The age of diagnosis of relatives was only seen as relevant for diabetes where there was uncertainty about the differences between early and late onset forms. A few diagnoses of heart disease or cancer were dismissed as being inevitable in old age, but mostly the age at diagnosis was not reported spontaneously, although it usually could be given when asked for.

People with two or more affected relatives who felt at increased vulnerability were no more likely to feel that their family health history was the reason than people with just one affected relative. This was true for all three disorders although the sample sizes were very small (table 5). However, nearly half the people who reported having affected relatives did not feel this was relevant to their own susceptibility. Forty one percent of the people who reported two or more relatives with heart disease and $58 \%$ who reported two or more relatives with cancer did not feel at increased susceptibility for any reason. For diabetes two out of the five people reporting two affected relatives did not feel at increased susceptibility.

\section{QUALITATIVE DATA}

Interpretations of family health histories

If an occurrence of a disease was reported within a family it was rarely seen to increase a 


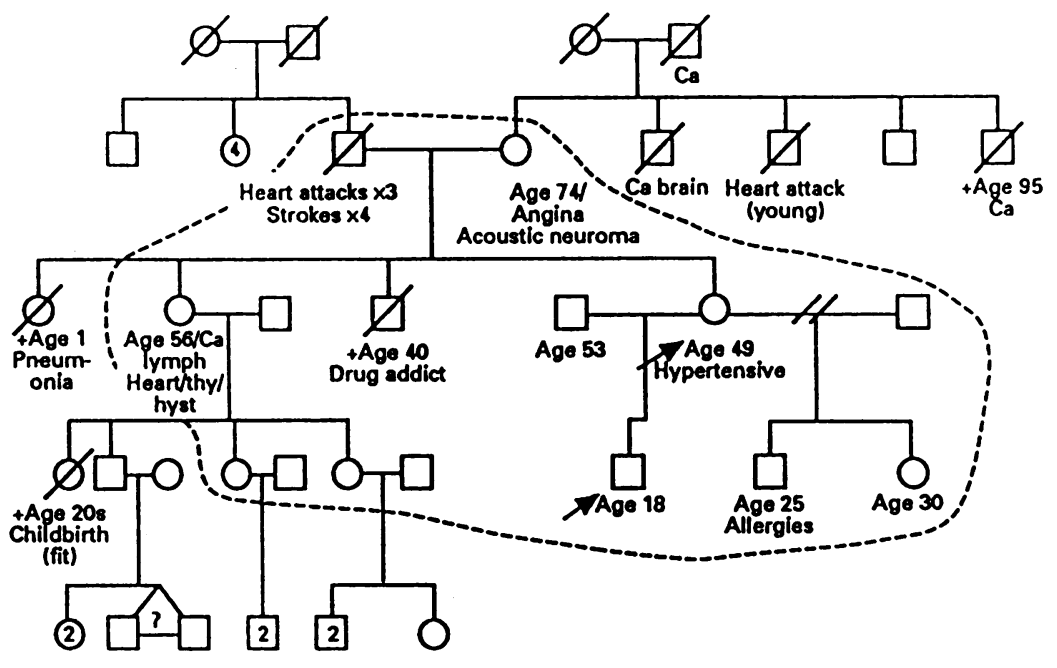

$\mathrm{Ca}=$ Cancer

Heart/thymyst = heart and thyroid disease, hysterectpmy

Figure 3 Pedigree of one family. Dotted line is the extent of family reported by young person. Differences of information: age at death of drug addict reported by young person as 25; age of aunt reported as 45 not 56 and no illness reported; angina in grandmother not reported; multiple strokes and heart attacks in grandfather not reported but death reported as from heart disease. All the names of diseases are as they were reported by the interviewees.

person's risk in a straightforward way. It was typically interpreted in one of three ways.

(1) It was seen as a chance occurrence or the result of the lifestyle or environment of the affected relative(s), and thus implied no inherited susceptibility for the interviewee, for example, an adult male being questioned about his two brothers, mother, and several uncles who developed heart disease at young ages.

I. "There are quite a lot of people with heart problems (in your family). Why do you think that is?"

Table 4 Number (\%) of respondents reporting 0 , 1, or more than one relative with heart disease, cancer, or diabetes by respondents' age and sex

\begin{tabular}{|c|c|c|c|c|}
\hline $\begin{array}{l}\text { No of } \\
\text { relatives }\end{array}$ & $\begin{array}{l}\text { Young } \\
\text { male }\end{array}$ & $\begin{array}{l}\text { Young } \\
\text { female }\end{array}$ & Fathers & Mothers \\
\hline $\begin{array}{l}\text { Heart disease } \\
0 \\
1 \\
2 \text { or more } \\
\text { (Parents report }\end{array}$ & $\begin{array}{c}9(39) \\
8(35) \\
6(26) \\
\text { ses of hea }\end{array}$ & $\begin{array}{l}6(17) \\
19(54) \\
10(29) \\
\text { se than yo }\end{array}$ & $\begin{array}{c}4(21) \\
5(26) \\
10(53) \\
\text { ple }(\mathrm{p}<0 .\end{array}$ & $\begin{array}{r}5(14) \\
5(14) \\
25(72)\end{array}$ \\
\hline $\begin{array}{l}\text { Cancer } \\
0 \\
1 \\
2 \text { or more } \\
\text { (Parents report } \\
\text { (Males were sig } \\
(p<0.05) \text { ) }\end{array}$ & $\begin{array}{r}10(43) \\
6(26) \\
7(31) \\
\text { ntly more } \\
y \text { more lik }\end{array}$ & $\begin{array}{c}11(31) \\
15(43) \\
9(25) \\
\text { f cancer th } \\
\text { females t }\end{array}$ & $\begin{array}{c}6(32) \\
1(5) \\
12(62) \\
\text { ng people } \\
\text { families }\end{array}$ & $\begin{array}{l}3(9) \\
11(31) \\
21(60) \\
05)) \\
\text { cases of cancer }\end{array}$ \\
\hline $\begin{array}{l}\text { Diabetes } \\
0 \\
1 \\
2 \text { or more }\end{array}$ & $\begin{array}{rr}21 & (91) \\
2 & (9) \\
0 & \end{array}$ & $\begin{array}{r}25(71) \\
7(20) \\
3(9)\end{array}$ & $\begin{array}{rr}17 & (90) \\
1 & (5) \\
1 & (5)\end{array}$ & $\begin{array}{r}24(69) \\
10(28) \\
(3)\end{array}$ \\
\hline
\end{tabular}

Table 5 Number of people who felt increased vulnerability because of having one or more than one affected relative

\begin{tabular}{lllll}
\hline Disease & $\begin{array}{l}\text { No reporting a } \\
\text { single affected } \\
\text { relative }\end{array}$ & $\begin{array}{l}\text { \% who felt } \\
\text { vulnerable owing } \\
\text { to inheritance }\end{array}$ & $\begin{array}{l}\text { No reporting two } \\
\text { or more affected } \\
\text { relatives }\end{array}$ & $\begin{array}{l}\text { \% who felt } \\
\text { vulnerable owing } \\
\text { to inheritance }\end{array}$ \\
\hline Heart disease & 37 & $27 \%(10)$ & 51 & $43 \%(22)$ \\
Cancer & 33 & $18 \%(6)$ & 49 & $29 \%(14)$ \\
Diabetes & 20 & $45 \%(9)$ & 5 & $60 \%(3)$ \\
\hline
\end{tabular}

R. "I think chance, a lot of it. I think a lot of it in [another country] is diet ... and most of them smoke. Smoking and diet mainly but of course there's the stress of where you live ..."

(2) The possibility of inherited susceptibility was acknowledged, but was not seen as a real threat because the interviewees saw their own actions as counterbalancing this. For example, a mother talking about heart disease:

"... it bothers me, but I think they had the wrong diet ... I think our diets are healthier, our generation is healthier. I suspect that statistically I am more susceptible to it, but it doesn't bother me because I believe that the risk is ameliorated by my lifestyle ..."

(3) The possibility of an inherited predisposition was acknowledged, but was not seen as a direct threat because the interviewee believed that "they did not take after that side of the family".

"Breast cancer runs in Mum's side of the family (maternal grandmother only) ... I probably won't get it because I'm more like my Dad" (17 year old girl).

\section{Explanations of inheritance}

There were a few people who had experienced genetic counselling who were able to some extent to give a mendelian explanation for the condition for which they had had advice. However, these same people did not extrapolate these explanations when discussing the inherited factors in common diseases or inheritance in general, for example, a father, when asked if he could explain the skipping of a generation in the condition for which he had been given genetic counselling.

R. "The normal possession of the (predominant symptom) is the dominant feature, 
and it just happened that the genes fell that way ... we went for genetic counselling which was quite helpful, in that he gave us a numerical risk sort of thing."

I. "Do you know how genetics works at all? Do you know what a gene is?"

R. "I don't, no. I just know it's something in you. I mean it's to do with the blood isn't it? ... I don't know really. It's something in the body."

Others of both generations used the words "genes" and "inheritance" but were unable to explain these. The young people commonly resorted to saying they did not know or could not explain while the adults were more likely to try and give an explanation.

For example, two different mothers said:

"Is it from the mother's family? Are the genes to do with the mother's side? I don't know. I understood that's what it was."

"Well if something runs in the family like hearts, there's a good chance that you - you've got a good chance of inheriting. You get your genes from your - I mean if you look the same, your eyes are the same ... there's no reason why you shouldn't get every other part really."

Like others, this mother, although she uses the word "gene", thinks in terms of physical features or diseases themselves being inherited rather than in terms of a mendelian explanation involving the inheritance of genes that are physical entities separate from, but influencing the development of, characteristics including susceptibility to disease.

To explain why some people in a family escape disease, or why there are variations in the age of onset, the concept of a "trigger" was often used. Respondents described how one could inherit a condition but there would be no overt disease unless there was something else that provoked it. In heart disease this would typically be stress, poor diet, smoking, or lack of exercise, all factors over which a person had some control. For cancer and diabetes, lifestyle factors were sometimes seen as triggers but most of the trigger factors were seen as unknown and beyond the person's control. Usually this idea was combined with perceived inherited susceptibility but was also used more widely.

"Cancer's inherent in everybody without exception, lying there dormant, it just needs triggering off." (Young person, not referring to inheritance.)

... [diabetes] is like cancer ... it's there it's just whatever the trigger point is. (Mother talking about her daughter's diabetes which she understood does have an inherited basis.)

Variable types of the same disease or sometimes a disease which apparently "skipped" a generation (which might be described by a geneticist as variable expression or incomplete penetrance of a genetic mutation or inheritance of a recessive condition) would be seen by the respondents as an inherited susceptibility modified in individual cases by factors such as lifestyle. Hence all sorts of cancers in a family would be explained by a mixture of environmental and other unknown factors, but the cancer itself was seen as "in the family".

\section{Comparisons between diseases}

The three conditions were viewed very differently in terms of seriousness, treatability, and controllability. Cancer was the most feared with diabetes typically seen as not frightening at all.

"Well, it (diabetes) is not something that's a problem. It's not a problem for me because you can be cured and sorted out." (Mother). "I'd rather die of a heart attack than something like cancer, you know, if it's quick. But not yet." (Mother).

A surprising finding was that cancer was sometimes viewed as an exclusively female problem whereas both heart disease and diabetes were seen to affect the sexes equally.

"But I think it's more women that get cancer, I think - well, that's what it seems like to me, so it doesn't bother me." (Son).

\section{Discussion}

Different factors were given different weight in the aetiology of the three conditions. Family health history was seen as more relevant to heart disease and diabetes than cancer, actions and behaviour as important for heart disease and cancer but less so for diabetes. Chance, on the other hand, was clearly the residual, the "explanation" to be invoked in the absence of other satisfactory explanations. Thus it would seem that heart disease is generally seen as explainable, in contrast to the other two diseases, since chance was seen as an important factor in cancer and diabetes, but was barely mentioned in connection with heart disease. This suggests that the health promotion messages about controlling heart disease have been received, an interpretation which is underlined by the fact that nearly a third of the sample were able to consider themselves less vulnerable than their peers to heart disease because of their own actions, principally diet and exercise. Like Weinstein, ${ }^{15}$ we found that people were more likely to cite their own actions as decreasing their susceptibility, while their family history and the environment, that is, factors beyond the person's control, were more likely to be seen as increasing it.

Few differences were found between men and women or between the generations in the reasons given for susceptibility. The major exception was that females of both generations were much more likely than males to feel susceptible to cancer because of affected relatives, and, in general, to believe that susceptibility to cancer was influenced by having affected relatives. It was clear that some of this sample perceived cancer as a female disease. The general media coverage about breast and cervical cancer and breast cancer genetics may have encouraged this idea, as well as the screening programme for the two diseases. 
There was much confusion about the different age of onset of diabetes. Twenty six percent of the total sample did not know if they were any more or less vulnerable to it than others. Adults were more likely than young people to feel that an absence of relatives with diabetes decreased their own susceptibility, probably because they felt that they must have passed the "at risk"/susceptible age.

Although words such as genes, chromosomes, and DNA were used by both generations there was no evidence of any understanding of the process of inheritance in scientific terms. The common perception was of the whole disease being passed directly from one person to another. As with infectious diseases where people talk about "germs", "viruses", and "bacteria" most people will think in terms of catching a cold or measles rather than thinking in terms of an infectious organism. Indeed there is much confusion between viruses and bacteria with many people expecting antibiotics for minor viral infections. ${ }^{16}$ Similar confusion exists when lay people talk about inheritance. Just as many people do not understand how the measles virus breathed in one day will give a rash some days later, so there may be a parallel in the lack of understanding of how a gene acquired from a parent will predispose to illness in adulthood. So in their everyday conceptualisations, just as the condition of measles or a cold is seen as being directly transferred from person to person without the mediation of viruses, so inheritance involves a direct transmission of conditions without the concept of genes. (For further discussion and implications for education see Richards. ${ }^{17}$ )

It was rare for anyone to feel at increased personal risk because of inheritance unless they reported at least one relative with the condition. This may seem an obvious observation but it may have implications for the acceptability of population genetic testing in the future when there may be instances of genetic susceptibility even without obvious family history because of variable and incomplete penetrance. It may also, in part, account for the lack of enthusiasm for cystic fibrosis carrier detection programmes that has been observed. ${ }^{18}$

Reporting of family health history was a little different between the sexes with men reporting less full histories. We felt that the interviews with both parents together were unsatisfactory at the history taking stage because the wives tended to either "correct" or else provide information instead of their husbands. Women in our culture are more interested in family matters and are usually the keepers of both family and health information. ${ }^{19}$ More girls and women were prepared to take part in this study reinforcing the idea that health is seen as a predominantly female matter. Most people could only report their family history as far back as grandparents. The information had not been passed on and each subsequent generation confined its knowledge to the same limits. This is the same observation made by others. ${ }^{13}$ The young people reported fewer relatives over all. Most of this is accounted for by the fact that adults report information about the generation above and below them whereas young people do not have a generation younger than themselves. However, the older generation in this study reported more fully on their near relatives than the younger people did. This contradicts the idea that family history is only learnt in childhood. ${ }^{13}$ Our results show that some acquisition of information carries on into adulthood although perhaps not about relatives who have already died. Family history information gathering about living kin is a continuing process with information being added as events occur. Also relationships within families are not static, and as there are changes in level of contact so information will be accrued.

\section{Conclusions}

Despite the fact that basic general genetics is being taught in schools, neither of the two generations in our study had integrated this into any understanding of their own perceived susceptibility to common disease. The young people in this group had only been taught the final two years of the new National Curriculum (there have been some modifications since this group were in school) and the curriculum may have more influence in the future. However, we should perhaps consider the extent to which it is appropriate to isolate the teaching of genetics within the science curriculum. As has been argued elsewhere, ${ }^{17}$ just as sex education has been placed in the context of personal and social development, so one might argue for the teaching of matters related to inheritance in the same context.

Integration of genetics teaching into health education units about specific diseases, where it can been seen in the context of other risk factors may encourage greater awareness of family health history which would allow people to build on their understanding of genetics within a personal framework.

The common disorders which have a genetic component are all multifactorial: this is generally how they are already perceived by both the age groups that we studied. It is important that we continue to encourage this view rather than emphasise genetics too much unless there is a proven benefit in identifying people at particular genetic risk. There was no evidence that people who felt at raised risk because of a family history also felt that health protection measures were redundant. Therefore, health education which combined both an understanding of the role of inheritance with other health promotion messages might be effective. This idea is reinfored by Kreuter and Strecher, ${ }^{20}$ who showed that individual interactive computer generated health education is effective in changing people's perceptions. The media has sometimes overemphasised the genetic factors of some diseases and given the public unrealistic expectations of what genetics can do. ${ }^{21}$ At present the actions that can be taken in the light of genetic information in common disease is limited to a very small number of people in families where the presence of specific genetic mutations can be dir- 
ectly demonstrated or inferred with high probability. However, this situation is likely to change and it is therefore important that families are encouraged to pass on accurate family health information and that more effective teaching about genetics is introduced in a way that will allow the public to benefit from new developments in the future.

This research was supported by a grant from the Health Promotion Research Trust. We would like to thank the students and their parents who took part and the staff of the Cambridge Regional College. We thank Sally Roberts for data management and graphics.

1 Fitzgerald FT. The tyranny of health. N Engl f Med 1994 331:196-8.

2 Welsh Planning Forum. Genomics: the impact of the new genetics on the NHS. June 1995.

3 Blaxter M, Paterson E. Mothers and daughters. London: Heinemann Education Books, 1982.

4 Richards MPM, Hallowell N, Green JM, Murton F, Statham $H$. Counselling families with hereditary breast and ovarian cancer: a psychosocial perspective. $\mathcal{F}$ Genet Couns $1995 ; 4$ : cancer:

5 Richards MPM. Families, kinship and genetics. In: Marteau T, Richards MPM, eds. The troubled helix: social and psychological implications of the new human genetics. Cambridge: Cambridge University Press, 1995.

6 Green J, Murton F, Statham H. Psychosocial issues raised by a familial ovarian cancer register. $\mathcal{F}$ Med Genet 1993; 30:575-9.

7 Davison C, Frankel S, Davey Smith G. Inheriting heart trouble: the relevance of common sense ideas to preventive measures. Health Education Research 1989;4:329-40.

8 Durant J, Hansen A, Bower M. Public understanding of the new genetics. In Marteau T, Richards MPM, eds. The troubled helix: social and psychological implications of the new human genetics. Cambridge: Cambridge University Press, 1995.

9 Department of Education and Science and the Welsh Office. Science in the national curriculum. London: HMSO, 1991.

10 House of Commons Science and Technology Committee. Human Genetics: the science and its consequences. 3rd report. Human Genetics: the science
London: HMSO, 1995.

11 Love RR, Evans AM, Josten DM. The accuracy of patient reports of a family history of cancer. $\mathcal{F}$ Chron Dis 1985; 38:289-93.

12 Kee F, Tiret L, Nicaud JY, McCrum E, Evans A, Cambien F. Reliability of reported family history of myocardial infarction. BMF 1993;307:1528-9.

13 Hastrup JL, Phillips SM, Vullo K, Kang G, Slomka L. Adolescents' knowledge of medical terminology and family health history. Health Psychol 1992;11:41-7.

14 Pope C, Mays N. Reaching the parts other methods cannot reach: an introduction to qualitative methods in health reach: an introduction to qualitative methods in
and health services research. $B M F$ 1995;311:42-5.

15 Weinstein ND. Why it won't happen to me: perceptions Weinstein ND. Why it won't happen to me: perceptions
of risk factors and susceptibility. Health Psychol 1984;3: 431-57.

16 Cope H, David A, Mann A. "Maybe it's a virus?": beliefs about viruses, symptoms, attributional styles and psychological health. F Psychosom Res 1994;38:89-98.

17 Richards MPM. Lay and professional knowledge of genetics and inheritance. F Public Understanding Sci (Submitted).

18 Richards MPM, Green JM. Attitudes towards prenatal screening for fetal abnormality and the detection of carriers of genetic disease: a discussion paper. $¥$ Reprod Infant Psychol 1993;11:49-56.

19 Stacey $M$. The new genetics: a feminist view. In Marteau T, Richards MPM, eds. The troubled helix: social and psychological implications of the new genetics. Cambridge: Cambridge University Press, 1996.

20 Kreuter MW, Strecher VJ. Changing inaccurate perceptions of health risk: results from a randomized trial. Health Psychol 1995;14:56-63.

21 Woman's Own, January 1994. 